\title{
Betegségreprezentáció és érzelmi állapot kapcsolata lymphomás betegeknél
}

\author{
Vincze Ágnes ${ }^{1}$, Megyeri Andrea $^{1}$, Losonczi Antónia ${ }^{2}$, Pintér Éva ${ }^{3}$, \\ Nagy Zsolt ${ }^{1}$, Demeter Judit ${ }^{1}$ \\ ${ }^{1}$ Semmelweis Egyetem ÁOK, I. sz. Belgyógyászati Klinika, Budapest \\ ${ }^{2}$ Eötvös Loránd Tudomány Egyetem, Pedagógiai és Pszichológiai Kar, Budapest \\ ${ }^{3}$ Semmelweis Egyetem ÁOK, Klinikai Pszichológiai Tanszék, Budapest
}

\begin{abstract}
Bevezetés: A betegségnek jelentést adó reprezentációs keret azonosítása alapvető ahhoz, hogy megértsük a betegek eltérő viselkedését; csoportos felmérése azonban számos kihívást tartogat. Megbízható, betegségspecifikus mérőeszközök hiányában a betegségreprezentációról a betegségnarratíva központi metaforája mentén is képet kaphatunk. Célkitüzés: Pilotvizsgálatunk célja lyphomával élő betegek betegségnarratíváinak feldolgozása, az ezekben fellelhető metaforák csoportosítása, illetve annak felmérése, hogy az egyes metaforák megjelenése mellett milyen érzelmi állapot azonosítható. Módszer: Kvalitatív adatgyüjtésünk félig strukturált interjúhelyzetben történt. A metaforák, illetve más értelemadó keret megjelenését és csoportosítását 2 független megítélő végezte. A betegek emellett 10 fokú vizuális-analóg skálán értékelték azt, hogy a beszámolójuk mennyire volt érzelmi szempontból felkavaró. Statisztikai analízis: A kvantifikált adatokat egyszempontos varianciaanalízis segítségével elemeztük. Eredmények: Vizsgálatunkban 27 lymphomával élő beteg vett részt. A beszámolók 40,7\%-ában volt metafora azonosítható, amelyből 29,6\% „harc”, $11,1 \%$ „út” metafora kategóriába sorolható. A „harc” metafora mellett olyan mértékben jelentek meg intenzív érzelmek, mint abban az esetben, amikor a személy számára nem volt előhívható semmilyen értelemadó keret, amire a helyzete értelmezésében támaszkodhatna. Következtetések: A vizsgált lyphomás betegeknél a daganatos betegségekben jellemző metaforák jelentek meg. A „harc”-cal kapcsolatos metaforák a biológiai működés leírásában is alapvetők, meghatározzák a közgondolkodást. Krónikus betegségekben a „harc”-os metaforák a betegséggel való szembesülés kezdeti időszakát követően kevésbé kidolgozott betegségreprezentációra utalhatnak, ami intenzívebb érzelmi állapottal jár. Vizsgálatunk megerősíti a feltevést, miszerint a reprezentáció befolyásolásával lehetőség nyílhat a betegséggel együtt járó érzelmi állapot módosítására. A fogalomkör meghatározott betegcsoporton belüli pontosabb megértése elvezethet specifikus, betegségreprezentációt mérő eszköz kidolgozásához.
\end{abstract}

Kulcsszavak: betegségreprezentáció, betegségnarratíva, metafora, érzelmi állapot

\section{Illness representation and emotional outcomes in patients living with lymphoma}

Introduction: To understand the distinct behaviour of individual patients it is essential to identify the frame through which they interpret their disease, however the assessment of such frames hold many challenges. Although it is difficult to get reliable illness specific instruments, the main metaphors in the patients' illness narratives can give us a better understanding of their illness representations. Aims: The aim of our pilot study was to analyse the illness narratives of lymphoma patients in order to identify and classify underlying metaphors, and subsequently ascertain correlations between the observed metaphors and the patients' emotional state. Method: Qualitative data acquisition was performed through semi-structured interviews. Metaphors and interpretive frames appearing in the narratives were identified by 2 independent observers. The emotional distress caused by the recalled narrative was graded by the subjects on a 10-grade visual-analogue scale. Statistical analysis: The quantified data was evaluated through one-way analysis of variance. Results: Twenty-seven lymphoma patients were enrolled. Metaphors identified in $40 \%$ of their narratives, of which $29 \%$ could be classified as "war", and $11 \%$ as "journey" metaphors. The development of intensive emotional states was observed in similar frequency in patients who used war metaphors in their narratives, as in individuals lacking interpretive frames which would help define their situation. Discussions: Metaphors typically associated with malignant diseases were used by the lymphoma patients. War metaphors are often used in the description of biological functions, thus influencing general perception. Among patients suffering from chronic disease the use of war metaphors after the initial confrontation period may indicate less structured illness representation, which entails a more

@ Levelezési cím: Vincze Ágnes, I. sz. Belgyógyászati Klinika, 1083, Budapest, Korányi Sándor u. 2/A,

E-mail: vincze.agnes@med.semmelweis-univ.hu, Tel.: +36206663440 
intensive emotional state. Our study to contributes the assumption that intervention on illness representations may modify disease associated emotional state. The deeper understanding of this concept could lead to more specific, illness representation measuring instrument.

Keywords: illness representation, illness narratives, metaphor, emotional state

(Beérkezett: 2020. június 3.; elfogadva: 2020. június 22.)

\section{Bevezetés}

Az egészség és betegség kognitív reprezentációival kapcsolatos munkák kiindulópontja Leventhal, Meyer és Nerenz majd 40 éve publikált tanulmánya volt, amely abból az alapvetésből indult ki, hogy a betegségekhez való alkalmazkodás aktív problémamegoldási folyamat eredménye [1]. Ez az egyszerű felvetés és a mögötte álló elmélet a mai napig keretet ad annak, ahogyan a betegségek egyéni, szubjektív leképeződéséről gondolkozunk. Segítségével magyarázatot adhatunk olyan, az orvosi gyakorlat során nap mint nap felmerülő kérdésekre, mint pl. miért szedi az egyik beteg a gyógyszerét, míg a másik nem, vagy miért viseli az egyik beteg könnyebben, a másik nehezebben az állapotát.

A betegségreprezentáció fogalmának megértéséhez elég csupán elképzelnünk, ahogy egy múzeumban éppen egy képet szemlélünk: lehetséges, hogy megfigyeljük a keret mintázatát, a képen ábrázolt forma emlékeket, élményeket idéz fel bennünk, esetleg futólag arra gondolunk, hogy a festő milyen művészeti irányt képvisel, ahogyan a színekre vagy épp színtelenségre is reagálunk. A megfigyelt kép tehát nem fényképszerủen kerül az elménk egy polcára, hanem olyan összetett mentális anyag formájában tárolódik, amely magában foglalja egyéni látásmódunkat, kulturális hagyományunkat, emlékeinket, érzéseinket és így tovább. Ehhez hasonlóan hozzuk létre az egészségi állapotunkkal kapcsolatos elképzeléseinket, betegségreprezentációinkat is. A betegségrôl ily módon kialakult kép mindent elmond arról, hogy a beteg mit gondol a betegsége mibenlétéről, mit tekint a betegség lehetséges okának, rövid vagy hosszú lefolyásúnak tartja-e az állapotát, kontrollálhatónak, befolyásolhatónak véli-e azt, ha igen, milyen eszközöket talál megfelelőnek az állapot alakítására, milyen érzelmeket él át, ha betegségére gondol. Mindezek miatt a betegségreprezentáció az utóbbi évtizedekben a krónikus betegségek megélésére, életminőségre, adherenciára vonatkozó vizsgálatok középpontjába került. Ennek megfelelően néhány éve a hematológiai tudományos diskurzusban is felmerült az igény adott betegcsoport betegségreprezentációjának hatékony felmérésére [2].
Az egyén betegségreprezentációjának feltérképezése magától értetődő feladat: meg kell kérnünk a személyt, hogy mondja el betegsége történetét (betegségnarratíva), a betegségreprezentáció összetevőit egyenként lekérdezhetjük, a tényszerú megállapítások mellett figyelve a beszámoló egyéni színezetére, a megfogalmazás módjára. Ezzel szemben a betegségreprezentáció felmérése csoportos, vizsgálati helyzetben korántsem ennyire magától értetődő, aminek az oka, hogy a betegségreprezentációk mint minden elemében szubjektív komplexumok - unikálisak. A betegségreprezentációk kérdőíves felmérése tehát mindenképp alapvető adatveszteséggel jár, amit egyedül a konkrét betegcsoport szempontjait pontosan megismerő kérdőívalkotás tud csak redukálni valamelyest (előzetes mélyinterjúkkal, majd fókuszcsoportos vizsgálattal), ilyen kérdőívek azonban egyelőre az egyes hematológiai betegségekre vonatkozóan nem elérhetők. (Krónikus myeloid leukémia kapcsán dokumentáltak már ilyen irányú törekvéseket [2].) További lehetőség a betegségreprezentáció felmérésére vagy annak egy szegmensére az, ha pl. a kezelőorvos pontozza, hogy az egyes beteg a megítélése szerint mennyire érti a betegségét, mennyire tekinthető hitelesnek a betegségével kapcsolatos elképzelés, ami szintén számos torzítási lehetőséget rejt magában. A fentieken túl a betegségreprezentáció megragadásának lehetséges módja az is, ha a betegségtörténeteket a bennük megjelenő központi metaforák mentén csoportosítjuk, aminek szintén van hagyománya [3-5]. A kognitív nyelvészet egyik legnagyobb figyelmet kapó és számos távoli tudományterületen is tovagyưrüző felismerései közé tartozik, hogy a metafora nem csupán nyelvi díszítóeszköz. A metaforák az emberi gondolkodás és megértés alapvető eszközei, nem pusztán plasztikusan leírnak valamit, rendezik is a tapasztalatot, új jelentést hoznak létre [6]. Így tehát a betegségnarratívák (betegségbeszámolók, betegségtörténetek) során tetten ért metaforák olyan sürített utalások, amelyek a betegségreprezentáció esszenciáinak tekinthetők.

A hétköznapokban mindannyian használunk metaforákat, többnyire anélkül, hogy ennek tudatában lennénk: ebben a pillanatban például megvilágitjuk a metafora kérdéskörét, melynek nyomán reményeink szerint az olvasó fejében szöget üthet néhány magvas gondolat. A minden- 
napi kommunikáció során absztrakt fogalomköröket egyszerübb fogalmakkal szemléltetünk, amelyek gyakran tartósan együtt járnak: például egy kapcsolat „zátonyra fut”, a felek „válaszúthoz érkeznek” vagy „rögös út előtt állnak” (jelen esetben a párkapcsolat az 'út/utazás/jármü'-re vonatkozó képekkel kapcsolódott össze tartósan) [7]. A betegségelbeszélésekben gyakran használt metafora és téma ugyancsak az utazás, végzet, szabadság, adomány, hatalom, ébredés, harc, nyitottság, nyitás a krízisre [3], ahol a metafora fogalmának értelmében a betegek tapasztalata nem csupán olyan, mint egy utazás, hanem magának az úton létnek a tapasztalata [8]. Daganatos betegségekben a harccal, úttal, és sporttal kapcsolatos metaforákat találták legjellemzőbbnek a vizsgálatok [4].

Vizsgálatunk tárgya a lymphomás betegek betegségnarratíváinak feldolgozása, az ezekben fellelhető metaforák csoportosítása, illetve annak felmérése, hogy az egyes metaforák megjelenése mellett milyen érzelmi állapot érhető tetten. Tesszük ezt azzal a céllal, hogy ellenőrizzük - a különböző betegségreprezentációkra utaló metaforák segítségével -, hogy a betegségreprezentáció kidolgozottsága, milyensége az elméleti megfontolásoknak megfelelően kísérletileg is igazolhatóan eltérő intenzitású érzelmekkel jár-e együtt.

\section{Módszer}

Keresztmetszeti, pilotvizsgálatunkban a betegségnarratívák gyüjtése félig strukturált interjúhelyzetben történt, amely során arra kértük a kúraszerű ellátásban megjelenő, legalább egy éve diagnosztizált, non-Hodgkin- vagy Hodgkin-lymphomával élő betegeket, mondják el betegségük történetét az első tünetek megjelenésétől az interjú napjáig. A vizsgálat személyes jellege és emiatt elfogadhatósága érdekében adatgyüjtésünk anonim módon zajlott. A metaforák, mélyebb betegségreprezentációs tartalmak megjelenését az alábbi kérdésekkel ösztönöztük: „Amikor a betegségére gondol, mi jut eszébe? Hogyan képzeli el, elképzeli-e valahogy a betegségét? Hogyan képzeli, hogy hat a kezelés?” A fenti kérdés megválaszolását követően azt kértük, hogy egy 10 fokú vizuális-analóg skála segítségével ítéljék meg, hogy a felidézett kép vagy gondolatsor érzelmi szempontból milyen mértékben volt felkavaró.

A megjelenő és lejegyzett képek azonosítását és csoportosítását két független megítélő végezte (P.É. és L.A.).
Egyet nem értés esetén a független besorolást követően a két megítélö közös döntést hozott. (Utóbbira 2 alkalommal volt szükség.) Ezeken túl a megítélők rögzítették, ha a személy beszámolójában metafora nem jelent meg, de más értelemadó keret (pl. vallásos világnézet) végigvonult a beszámolón.

A kvantifikált adatokat SPSS 22.0 (IBM Corp. Released 2013. IBM SPSS Statistics for Windows, Version 22.0. Armonk, NY: IBM Corp.) statisztikai programmal, egyszempontos varianciaanalízis (ANOVA) segítségével, LSD-korrekciót alkalmazva elemeztük. A metaforák nem és korcsoport szerinti (<35 év / 35-50 év / >50 év) eloszlását khi-négyzet-próbával ellenőriztük.

Vizsgálatunkat az Egészségügyi Tudományos Tanács, Tudományos és Kutatásetikai Bizottság (ETT-TUKEB) engedélyezte, engedélyszám: IV/663-2/2020/EKU.

\section{Eredmények}

Vizsgálatunkban 27 lyphomával élő beteg vett részt, a résztvevők mindegyike a vizsgálat idején kezelésben részesült. Részvételi arány: $100 \%$, egyetlen, a vizsgálatra felkért személy sem utasította el a részvételt. A nemek eloszlása közel azonos volt (12 férfi, 15 nő), medián életkor 56 év. A khi-négyzet-próba eredménye szerint sem a nemek $\left(X^{2}=1,632, p=0,652\right)$, sem az életkori csoportok között $\left(X^{2}=5,138, p=0,526\right)$ a metaforák típusának eloszlásában nem mutatkozott különbség. A beszámolók 40,7\%-ában volt metafora azonosítható, amelyből 29,6\% „harc”, 11,1\% „út” metafora kategóriába sorolható volt. 44,4\%-ban ugyan metafora nem jelent meg a beszámolóban, de azonosítható volt a betegséget és a személy helyzetét magyarázó értelemadó keret pl. vallásos hit vagy olyan világnézeti rendszer, amelyben a beteg a történéseket el tudja helyezni. 14,8\%-ban sem metafora, sem más értelemadó keret nem volt tetten érhető. Az eredményeket az 1. táblázat szemlélteti.

Példák a betegséget magyarázó metafora előfordulására: 1. „Harc” - kategória: „Az történik, hogy a jó sejtek megeszik a rosszakat, ebben a kezelés segít, felállítok egy hadsereget, ami elkezdi pusztítani a rosszakat. A kezelés ebben segít, ahogy próbálja akadályozni, hogy ne a jó, hanem a rossz sejtek pusztuljanak.” 2. „Utt” - kategória: „Az fogalmazódott meg bennem, hogy születésünk pillanatától menetelünk a halál felé, azt, hogy ezt hogyan érjük

1. táblázat. A betegségnarratívákban előforduló metaforák és egyéb értelemadó keret gyakorisága

\begin{tabular}{lccc}
\hline$N($ elemszám) $=27$ fö & Metaforakategória & Gyakoriság (\%) \\
\hline Metafora előfordult & „Harc” & 29,6 & 40,7 \\
\hline Metafora nem, de más értelemadó keret megjelent & „Út” & 11,1 & 44,4 \\
\hline Egyik sem tetten érhető & & & 14,8 \\
\hline
\end{tabular}




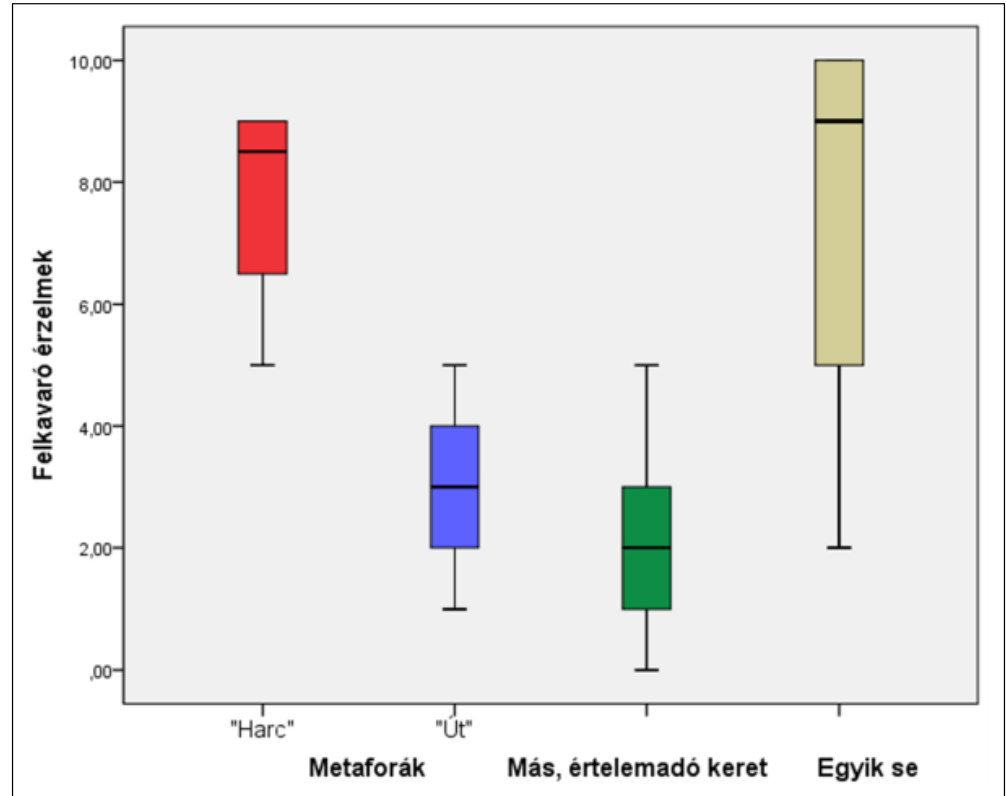

1. ábra. A felidézett érzelmi állapot intenzitásában megjelenő különbségek az egyes csoportokban

el, nem is olyan fontos. Így amíg lehet, a szinten tarásra törekszem."

Példa metafora hiányára: 3. Más értelemadó keret tetten érhetö: „Nem foglalkozom vele egyáltalán. Van hitem, ami magyarázatot ad az életre, a betegségre, és ha arról van szó, az elmúlásra is." 4. Sem metafora, sem értelmet adó magyarázó keret nem jelenik meg a kérdés nyomán: „Nem pajzsmirigy... nem jut eszembe... magyarul: rák."

A felidézett érzelmi állapotban szignifikáns különbségek jelentkezett a "harc” (átl. $=7,75 ; s=1,58)$ és „út" (átl. $=3 ; s=2,0)$ metaforát használó $(p=0,002)$; a "harc" metaforát és a "metaforát nem, de értelemadó keretet” használó (átl. $=2,17 ; s=1,4 ; p=0,000$ ), az „út" metaforát használó és a „sem metaforát, sem értelemadó keretet nem használó" (átl. $=7,5 ; s=3,7 ; p=0,007$ ); a „metaforát nem, de értelemadó keretet” használó, illetve a „sem metaforát, sem értelemadó keretet nem használó" ( $p=$ $0,000)$ csoportok között. Az érzelmi állapot intenzitásában mutatkozó különbségeket az 1. ábra szemlélteti.

\section{Megbeszélés}

Vizsgálatunkban a vizsgálati személyek alacsony száma ellenére a daganatos betegségekben jellemző metaforák megjelentek [4], a metaforák használata a betegek majd felénél tetten érhetô. Többségében harccal, háborúval kapcsolatos metaforák, kisebb arányban út, utazás metaforák jelentkeztek. Az eredményekből szembetűnő, hogy a háborús metaforák mellett éppen annyira felkavaró érzelmi állapot detektálható, mintha valaki sem metaforát, sem egyéb értelemadó keretet nem használt az elbeszélésében. Míg az út metaforák mellett legalább annyira nyugodt érzésekről számoltak be a résztvevők, mintha más értelemadó keret, pl. vallásosság segítette a személyt a történések értelmezésében.

A harccal, háborúval kapcsolatos metaforák megjelenése azon túl, hogy a daganatos betegek beszámolóiban gyakran előfordulnak, nagyarányú jelenlétük azért sem meglepő, mert ezek a képek a biológiai összefüggésekkel tipikusan tartós kapcsolatban lévő, különösen az immunrendszer leírására gyakran használt metaforák. Például: az immunsejtek küzdenek, felveszik a harcot, felismerik a betolakodót stb. Talán ennek az állandósult kapcsolatnak a nyomán férkőzött be a közgondolkodásba, hogy a „daganatos betegséggel fel kell venni a harcot”, a betegnek ,küzdenie kell a gyógyulásért". A küzdelem nyilvánvaló erőfeszítéssel, felfokozott érzésekkel jár. A fenti frázisok gyakran a tévesen értelmezett „pozitív gondolkodás” részei is, amit a környezet gyakran el is vár a betegtől, olykor azt eredményezve, hogy a beteg nem engedi meg magának a negatív érzéseket, a nehéz élethelyzettel való szembenézést. Az életet fenyegető betegség tapasztalata mint trauma a személy életét gyakran előtte-utána állapotra bontja, ami a mindannyiunkra jellemző önazonosságra törekvést tartósan vagy átmenetileg megzavarja. A történtek értelmezése, a jelentésadás igénye az, ami a megszakadt narratív koherenciát képes visszaállítani. Ez azonban csak a helyzettel való szembenézés árán valósulhat meg [8].

Eredményeink értelmezését segítheti Frank [9] elképzelése, aki a betegségtörténetek három altípusát különítette el:

1. helyreállitó narrativák, amelyek az egészség helyreállításáról szólnak az orvostudomány segítségével. Az elbeszélt történet íve többnyire: jóllét, majd beteggé válás, kezelés, gyógyulás, végül a betegség elötti állapot ismételt elérése. A helyreállító narratíva jövőközpontú, a gyógyu- 
lásra épít, ezzel érintetlenül hagyva a múltat és a személy öndefinícióját is. Ez a narratíva súlyos krónikus betegség esetén gyakran csapdát jelenthet, mivel az élet vagy csak átmenetileg, vagy egyáltalán nem lesz olyan, mint a betegség előtt. A háborús metaforák többnyire a helyreállító narratíva logikáját követik.

2. alcsoportként Frank a káosz narrativát azonosította. Eszerint a szenvedés túl nagy ahhoz, hogy el lehessen mondani, a beszélő nem bír vele. Az elbeszélő meggyőződése, hogy az élet soha nem zökken helyre. A betegséghez való ilyen viszony akkor áll elő, ha a beteg sem a régi énjéhez nem talál vissza, sem újat nem épít ki. A metafora, illetve más értelemadó keret hiánya utalhat káosz narratíva jelenlétére.

A 3. típus az ún. kereső történeteké, ahol a narratíva alanya elfogadja az élet esetlegességét. Ezekben az elbeszélésekben gyakran megjelenik a beteg útja, utazása, illetve sajátos, egyénileg jellemző metaforák azonosíthatók. Ebben az esetben tehát a beteg képes ismét koherensnek látni múltját és jelenét, elfogadja helyzete megváltozottságát, tudatos tapasztalatokat nyer, érettebbé válik. Ahogyan Frank, Paterson váltakozó perspektívák modellje [10] is hangsúlyozza, hogy a betegség megélése folyamatosan változó, eltolódó perspektívákként képzelhető el, tehát a fenti kategóriák általában nem egymástól függetlenül, izoláltan jelennek meg. A betegség kezdetén gyakoribbak a helyreállító narratívák, míg a hosszabb ideje fennálló krónikus állapot lehetőséget ad a személynek arra, hogy többszörösen újraértelmezze a helyzetét, ami által a betegség trauma jellege tompul, a betegség ténye megtalálja a helyét az életesemények sorában, aminek köszönhetően a betegség gondolata már nem felkavaró. Harcra, háborúra jellemző metafora tehát jellemző lehet a) a betegség kezdetén, b) azokban az életet fenyegető akut állapotokban, ahol ez a kép reprezentálja leghitelesebben az aktuális történéseket, c) olyan krónikus állapotokban, ahol a személy megreked a legkönynyebben elérhető, sztereotip elképzeléseknél a betegsége értelmezésében. Utóbbi oka lehet a környezet elvárása, amely nem engedi meg, hogy a személy a nehézségeit megélje, azokról beszéljen, hanem egy mágikus gondolkodási rendszerben mozogva a reális negatív kimenetelre, nehézségekre vonatkozó gondolatokat letiltja. Ehhez hasonló tiltás jelentkezhet abban az esetben is, ha a személy eleve adott érzelmi teherbírása nem teszi lehetővé, hogy a betegségével kapcsolatban hosszabban gondolkozzon, elmélkedjen; illetve ugyancsak a könnyen elérhető, készen kapott elképzelések uralhatják a betegségreprezentációt akkor, ha a betegség mibenlétének megértése kognitív akadályba ütközik.

A betegségreprezentációk alakulása tehát spontán az idő előrehaladtával történik, támogatja, ha a személynek lehetősége van saját megélését megfogalmazni, aminek köszönhetően a történések elrendezhetővé válnak az élettörténetben. Ebben a beteg segítségére lehet a családja, barátai, amennyiben azok figyelmesen meghallgatják, illetve ugyanígy segítheti a folyamatot önsegítő csoport, pszichológus, de vizsgálatok szerint akár a kérdéses témáról szóló naplóírás is [11]. Eredményeink szerint a metaforák hozzájárulhatnak a betegségreprezentáció kidolgozottságának azonosításához, a betegségreprezentáció alakulási folyamatát kísérő érzelmek megértéséhez, illetve megerősítik a feltevést, miszerint a reprezentáció alakításával az érzelmi állapot befolyásolhatóvá válhat.

Vizsgálatunkkal kapcsolatos kritikai észrevétel, hogy az alacsony elemszám miatt az elvégzett statisztikai próbák megbízhatósága korlátozott, ami hatással van az eredmények interpretálhatóságára. Átfogó elemzésre (regreszsziós modellek használatára) jelen feltételek mellett nem kerülhetett sor, például a betegségkezdet óta eltelt idő és az azonosítható metaforák kapcsolata jelen esetben nem volt vizsgálható, illetve számos egészségügyi adat, amely segítené a metaforák előfordulásának értelmezését, felmérésünkben a vizsgálat anonimitása miatt nem szerepelhetett. Pilotvizsgálatunk azonban a módszer használhatóságát alátámasztja, a magas részvételi arány a bizalmas információk ellenére arra utal, hogy a vizsgálat elfogadottsága a későbbiekben a személyes és egészségügyi adatok figyelembevételével is megfelelő lehet. Mindezek miatt a vizsgálat kiterjesztése, objektívebb, célzott betegségreprezentációt mérő eszköz kidolgozása javasolt.

Nyilatkozat: A szerzők kijelentik, hogy a közlemény más folyóiratban korábban nem jelent meg, és máshová beküldésre nem került. A levelező szerző a szerzői útmutatót elolvasta. A cikk végleges változatát valamennyi szerző elolvasta és jóváhagyta.

Érdekeltségek: A szerzőnek nincsenek érdekeltségei.

Anyagi támogatás: A közlemény megírása, illetve a kapcsolódó kutatómunka anyagi támogatásban nem részesült.

Szerzői munkamegosztás: V.Á. - elméleti háttér, adatgyüjtés, adatelemzés, következtetések, L.A., P.É., - adatbevitel, adatfeldolgozás, M.A., N.Zs., D.J. - következtetések, a szöveg átdolgozása.

\section{Irodalom}

[1] Reinhardt M. Cognitive representations of chronic diseases: empirical study of correlation between illness cognition and selfdirectness. In: Demetrovics Z, Kökönyei G, Oláh A (eds). From personality psychology to health psychology. [Kognitív reprezentációk a krónikus betegségekről: betegségkogníció és önszabályozás összefüggéseinek empirikus vizsgálata. Személyiséglélektantól az egeszségpszichológiáig.] Budapest: Trefort; 2007. pp. 156-185. [Hungarian]

[2] Breccia M, Graffigna G, Galimberti S, Iurlo A, Pungolino E, Pizzuti $\mathrm{M}$, et al. Personal history and quality of life in chronic myeloid leukemia patients: a cross-sectional study using narrative medicine and quantitative analysis. Supportive Care in Cancer: Official Journal of the Multinational Association of Supportive Care in Cancer 2016.

[3] Hawkins AH. Reconstructing illness: studies in pathography. WL, P. Univ. Press; 1999. 
[4] Harrington KJ. The use of metaphor in discourse about cancer: a review of the literature. Clinical Journal of Oncology Nursing 2012; 16: 408-412.

[5] Oronsky B, Carter CA, Mackie V, Scicinski J, Oronsky A, Oronsky $\mathrm{N}$, et al. The war on cancer: a military perspective. Frontiers in Oncology 2014; 4: 387.

[6] Lakoff G, Johnson M. Metaphors we live by. University of Chicago Press. p. 2008.

[7] Kövecses Z. Metaphor: A Practical Introduction. New York: Oxford University Press; 2010. pp. 149-171.
[8] Pintér JN. Psychology of chronic diseases. Crisis and renewal. [A krónikus betegségek lélektana. Válság és megújulás.] Budapest: L'Harmattan; 2018. [Hungarian]

[9] Frank AW. The rhetoric of self-change: Illness experience as narrative. The Sociological Quarterly 1993.

[10] Paterson BL. The shifting perspectives model of chronic illness. J Nurs Scholarsh. 2001; 33: 21-26.

[11] Pennebaker JW. Expressive writing in psychological science. Perspect Psychol Sci. 2018; 13: 226-229.

A cikk a Creative Commons Attribution 4.0 International License (https://creativecommons.org/licenses/by/4.0/) feltételei szerint publikált Open Access közlemény, melynek szellemében a cikk bármilyen médiumban szabadon felhasználható, megosztható és újraközölhető, feltéve, hogy az eredeti szerző és a közlés helye, illetve a CC License linkje és az esetlegesen végrehajtott módosítások feltüntetésre kerülnek. (SID_1) 